\title{
Lei de Anistia e Justiça de Transição: a releitura da ADPF 153 sob o viés argumentativo e principiológico
}

\author{
Claudia Rosane Roesler ${ }^{1}$ \\ Laura Carneiro de Mello Senra ${ }^{2}$
}

Resumo: Neste trabalho, centrou-se na análise dos votos que constituem a Arguição de Descumprimento de Preceito Fundamental 153, ajuizada no Supremo Tribunal Federal em outubro de 2008, pelo Conselho Federal da Ordem dos Advogados do Brasil. O cerne da controvérsia constitucional se referia à interpretação do parágrafo $1^{\circ}$ do artigo $1^{\circ}$ da Lei de Anistia (Lei n. 6.683/79), que considerava conexos, para os fins de concessão de anistia, os crimes de qualquer natureza relacionados com crimes políticos ou praticados por motivação política. Pode-se dizer que os votos proferidos pelos Ministros e Ministras são consistente e coerentemente fundamentados e, por isso, atendem aos requisitos básicos de racionalidade e de impessoalidade. Contudo, parece haver uma incongruência entre a decisão da ADPF 153 - que entende válida a norma questionada - e os princípios e valores defendidos no Estado Democrático de Direito. Tal decisão, portanto, não se revela a mais adequada, em face do contexto em que foi tomada.

Palavras-chave: ADPF 153. Teoria da Argumentação. Estado Democrático de Direito.

\begin{abstract}
The main objective of this work was to analyze the Votes of the Ministers of the Brazilian Supreme Court in the case entitled "Arguição de Descumprimento de Preceito Fundamental 153" (ADPF 153). The constitutional issue presented in the ADPF 153 dealt with the interpretation of the first paragraph of the first article of the Brazilian Amnesty Law (Law number 6.683, from 1979). According to this paragraph, crimes of any nature, related with political crimes, or motivated by political intentions, could be amnestied. From the examination of the Votes of the Ministers, it can be said that they are consistent and coherent and therefore achieve the basic requisites of impersonality and rationality. Nevertheless, there see$\mathrm{ms}$ to be an incongruence between the decision that was taken in the case of the ADPF 153, and the principles and values promoted in the Rule of Law. Hence, we conclude that this decision can't be considered the most adequate, concerning the context in which it was taken.
\end{abstract}

Key words: ADPF 153. Argumentation Theory. Rule of Law.

1 Possui Pós-Doutorado em Direito pela Universidade de Alicante (Espanha). Doutora em Teoria e Filosofia do Direito pela Universidade de São Paulo. Professora Adjunta da Faculdade de Direito da Universidade de Brasília.E-mail: croesler@unb.br.

2 Graduanda em Direito pela Universidade de Brasília.E-mail: senra.laura@gmail.com. Recebido em: 23/09/2011.

Revisado em: 26/03/2012.

Aprovado em: 20/04/2012. 


\section{Introdução}

A argumentação encontra-se em um momento importante de renascimento na contemporaneidade. Mais precisamente, situa-se no quarto grande período do desenvolvimento das teorias da argumentação: o período da renovação. Sua marca distintiva é o aparecimento da "nova retórica"3, sobretudo após os trabalhos de Chaim Perelman, Stephen Toulmin e Theodor Viehweg.

Os fatores relacionados ao desenvolvimento das teorias da argumentação, como apresentado por Phillipe Breton e Gilles Gauthier, estão associados a certas considerações intelectuais e a um contexto social específico (BRETON; GAUTHIER, 2001, p. 11). O contexto específico a que se faz referência neste trabalho será o paradigma do Estado Democrático de Direito, como ordem jurídica à qual estão vinculados princípios e valores fundamentais, que são fruto do processo comunicativo dos sujeitos de uma determinada comunidade, e que orientam - ou pelo menos devem orientar - a ação. Em um contexto tal, a argumentação em relação à aplicação do direito se revela como persuasiva ${ }^{4}$, e não demonstrativa, a partir daqueles valores. (MACCORMICK, 2008, p. 2)

3 A obra Tratado da Argumentação - A nova retórica, de Chaim Perelman e Lucie Olbrechts-Tyteca é um verdadeiro marco no contexto do aparecimento da nova retórica. De acordo com os autores, "[...] nosso tratado se relaciona sobretudo com as preocupações do Renascimento e, conseqüentemente, com as dos autores gregos e latinos, que estudaram a arte de persuadir e de convencer, a técnica da deliberação e da discussão. É por essa razão também que o apresentamos como uma nova retórica. [...] outra razão, muito mais importante, a nosso ver, motivou nossa escolha é o próprio espírito com o qual a Antiguidade se ocupou de dialética e de retórica. O raciocínio dialético é considerado paralelo ao raciocínio analítico, mas trata do verossímil em vez de tratar de proposições necessárias. [...] [a] ideia de adesão e de espíritos aos quais se dirige um discurso é essencial em todas as teorias antigas da retórica. Nossa aproximação desta última visa a enfatizar o fato de que é em função de um auditório que qualquer argumentação se desenvolve." (PERELMAN; OLBRECHTS-TYTECA, 1996, p. 5-6)

4 A respeito dos argumentos persuasivos, afirmam Breton e Gauthier: "Explicita ou implicitamente, um argumento é sempre considerado como um conteúdo ou uma forma de conteúdo de comunicação. [...] afigura-nos bastante claro que uma característica fundamental do argumento [...] é o facto de se desenvolver numa situação de interrelação. [...] A conexão entre argumentação e persuasão prolonga-se na conexão entre 
Quando se fala em paradigma do Estado de Direito, pressupõe-se uma teoria institucional do direito, sendo que esta última está intimamente relacionada a duas ideias principais (MACCORMICK, 2008, p. 3). Em primeiro lugar, a ordem jurídica, como ordem normativa que se estabelece quando a vida em uma comunidade está orientada por um consenso razoável e segurança sobre as expectativas comuns. Em segundo lugar, o sistema jurídico, como ordem legal que existe em um determinado local, destinada a abarcar a ordem social que ali é encontrada. As normas de conduta que regulam as atividades das pessoas devem ser entendidas como inter-relacionadas umas às outras, de modo a formar um corpo único do direito, melhor dizendo, um sistema do direito.

A decisão judicial e os julgamentos institucionalizados apontam para questões de fundamental importância para o Estado de Direito, notadamente, a definição dos bons argumentos em um caso concreto, ou ainda, a distinção entre os bons e os maus argumentos em um processo de interpretação e tomada prática de decisões. Assim, analisar a consistência, a coerência, as consequências normativas, em suma, a estrutura argumentativa das razões oferecidas em decisões judiciais, revela-se uma tarefa bastante profícua. A Arguição de Descumprimento de Preceito Fundamental - ADPF 153 será o objeto central e ponto de partida da pesquisa aqui desenvolvida.

Parece proveitoso, antes de seguir adiante, deixar assentado um aspecto basilar da análise. Faz-se menção à importância da argumentação persuasiva, principalmente no atual contexto, sob a vigência do Estado Democrático de Direito. Assumindo tais ideias como linhas mestras, a questão que se coloca é a seguinte: será possível conciliar o caráter argumentativo do direito com o ideal do Estado de Direito? Para responder essa indagação, serão utilizados os ensinamentos de Neil MacCormick.

O caráter argumentativo do direito deve ser entendido como um primeiro lugar-comum (MACCORMICK, 2008, p. 19). Para que uma decisão seja considerada adequada, esta deve ser precedida de um debate e

argumentação e persuasão. Um argumento possui uma finalidade persuasiva intrínseca: procura suscitar a adesão de um interlocutor, ou de um auditório, a uma crença ou levá-lo a adoptar um comportamento.” (BRETON; GAUTHIER, 2001, p. 13) 
análise dos argumentos favoráveis e contrários, necessariamente. Nessa linha, pode-se dizer que o direito é uma disciplina sujeita à argumentação, nem sempre conclusiva, mas ao menos persuasiva.

O Estado de Direito seria, desse modo, um segundo lugar-comum (MACCORMICK, 2008, p. 22). É possível pensar em uma comunidade, na qual diversos valores são garantidos pela ordem institucional - a segurança jurídica, a certeza jurídica, a garantia dos indivíduos contra interferências arbitrárias do Estado, dentre outros -, e em que prevalece um corpo estabelecido e reconhecido de normas jurídicas. Assumindo que tal seria um Estado de Direito, os aspectos de maior importância se refeririam, portanto, à razoável certeza e segurança dos cidadãos a respeito das regras e expectativas que servem de parâmetro para a própria conduta e de outrem.

Com o intuito de fornecer uma resposta à questão colocada anteriormente, afirma-se que os dois lugares-comuns podem ser conciliados. Segundo MacCormick, “[...] os processos jurídicos se movem por meio de uma cadeia de certezas putativas que são a cada ponto passíveis de questionamento" (MACCORMICK, 2008, p. 37). Em outras palavras, a argumentação que se aperfeiçoa no decorrer do processo judicial, o processo interpretativo, bem como o silogismo final, que representa a decisão tomada em um caso concreto, consistem em certezas provisórias e excepcionáveis. A certeza do direito não se contrapõe ao caráter argumentativo, vez que se apresenta como uma segurança que convive em constante tensão com a possibilidade de questionamento.

\section{A Lei de Anistia e a ADPF 153}

Para aprofundar a reflexão sobre a articulação entre o caráter argumentativo do direito e o Estado de Direito, e também sobre o impacto que decisões judiciais das Cortes possuem na contemporaneidade, é essencial trazer para a análise um caso concreto. Neste trabalho, centrar-se-á, nomeadamente, nos votos proferidos pelos Ministros e Ministras do Supremo Tribunal Federal no caso emblemático da Arguição de Descumprimento de Preceito Fundamental 153. 
Em outubro de 2008, a ADPF 153 foi ajuizada no Supremo Tribunal Federal, pelo Conselho Federal da Ordem dos Advogados do Brasil. $\mathrm{O}$ cerne da controvérsia constitucional se referia à interpretação do parágrafo $1^{\mathrm{o}}$ do artigo $1^{\mathrm{o}}$ da Lei de Anistia (Lei n. 6.683/1979), que considerava conexos, para os fins de concessão de anistia, os crimes de qualquer natureza relacionados com crimes políticos ou praticados por motivação política.

Art. $1^{\circ}$ É concedida anistia a todos quantos, no período compreendido entre 02 de setembro de 1961 e 15 de agosto de 1979, cometeram crimes políticos ou conexos com estes, crimes eleitorais, aos que tiveram seus direitos políticos suspensos e aos servidores da Administração Direta e Indireta, de fundações vinculadas ao poder público, aos Servidores dos Poderes Legislativo e Judiciário, aos Militares e aos dirigentes e representantes sindicais, punidos com fundamento em Atos Institucionais e Complementares (vetado).

$\S 1^{\circ}$ - Consideram-se conexos, para efeito deste artigo, os crimes de qualquer natureza relacionados com crimes políticos ou praticados por motivação política. (BRASIL, 1979, art. $1^{\circ}$, grifos nossos)

Questionou-se se a norma impugnada teria sido recepcionada pela Constituição de 1988 e, ainda, se poderia ser interpretada e aplicada à luz dos princípios e normas consagrados na nova ordem constitucional. O pedido apresentado na Petição Inicial requeria que fosse conferida à Lei $6.683 / 79$

[...] uma interpretação conforme a Constituição, de modo a declarar, à luz de seus preceitos fundamentais, que a anistia concedida pela citada lei aos crimes políticos ou conexos não se estende aos crimes comuns praticados pelos agentes da repressão contra opositores políticos, durante o regime militar. (ORDEM DOS ADVOGADOS DO BRASIL, 2008, p. 29)

Em abril de 2010, a ADPF 153 foi julgada improcedente, nos termos do voto do Relator, o Ministro Eros Grau. Em número de sete votos contra dois, prevaleceu o entendimento segundo o qual a Lei de Anistia 
seria válida, por apresentar-se como instrumento de transição do regime ditatorial para o democrático. De acordo com este propósito conciliador, a anistia, conforme concedida pela Lei n. 6.683/79, contemplaria também os crimes praticados por agentes públicos do Estado.

Antes mesmo de se questionar sobre a correção da decisão como um todo, é imprescindível avaliar a estrutura argumentativa, bem como o atendimento aos requisitos básicos de racionalidade, dos votos que deram subsídio a esta decisão.

\section{Dos Votos para o Layout de Argumentos de Stephen Toulmin}

Alude-se, previamente, à importância em pautar os votos que constituem a decisão da ADPF 153. No que toca à metodologia utilizada, buscou-se transpor os argumentos centrais de cada voto da referida Arguição para um esquema racional de análise, proposto por Stephen Toulmin.

O filósofo defende a possibilidade de identificar fases análogas de desenvolvimento dos argumentos - não obstante possam pertencer a campos os mais diversos, ou serem objeto de inúmeras possibilidades de combinações de razões e proposições. Estrutura, portanto, um layout, um célebre modelo de análise, que será denominado "Esquema de Toulmin". Tal esquema será conformado a partir dos seguintes elementos (TOULMIN, 2001, p. 139-149):

a) Dados (data): são os fatos aos quais o indivíduo recorre como fundamentos para a alegação.

b) Conclusão (claim ou conclusion): é a alegação ou conclusão que se busca alcançar, com o desdobramento do argumento.

c) Garantias (warrants): seriam afirmações gerais (regras, princípios etc.) que atuariam como "pontes" para passar dos dados para a conclusão apresentada. Incidentais e explanatórias, teriam como função registrar a legitimidade e propriedade da "ponte" entre os dados e a conclusão. 
d) Apoio das Garantias (backing): atuariam como "avais" das garantias, de modo a assegurar a autoridade e vigência destas. Em cada campo, os apoios utilizados para sustentar as garantias irão variar de maneira expressiva.

e) Qualificadores Modais (qualifiers): surgem quando é necessário acrescentar uma referência ao grau de força que as garantias conferem à alegação. Pode-se citar alguns exemplos: necessariamente, presumivelmente, provavelmente etc.

f) Condições de Refutação ou de Exceção (conditions of rebuttal or exception): são capazes de invalidar ou refutar a conclusão que se tinha como garantida, por trazerem uma exceção às circunstâncias do caso.

Se todos esses elementos forem agregados, o Esquema de Toulmin pode ser delineado da seguinte maneira (TOULMIN, 2001, p. 150):

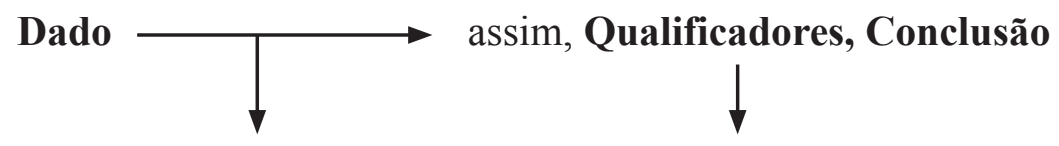

já que Garantia a menos que Condições de Refutação

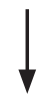

por conta de Apoio

O plano da análise exige que se faça uma tradução dos votos dos Ministros e Ministras para o Esquema de Toulmin. Após um exame minucioso do Inteiro Teor do Acórdão da ADPF 153, foram selecionados os argumentos centrais de cada voto, que serão apreciados em seguida.

\subsection{Ministro Eros Grau}

O Ministro Eros Grau, Relator da ADPF 153, argumenta no sentido da improcedência da ação que questiona a Lei de Anistia. Seis outros Ministros acompanharam seu entendimento - Carmen Lúcia, Ellen Gracie, Cesar Peluso, Gilmar Mendes, Marco Aurélio, Celso de Mello -, tornan- 


\section{do este voto o vencedor da ADPF 153. Passa-se, então, para a análise da estrutura argumentativa do voto.}

\subsubsection{A Ofensa ao Princípio da Dignidade Humana}

\begin{tabular}{|c|c|}
\hline Dado & $\begin{array}{l}\text { "A inicial ignora o momento talvez mais importante da luta pela redemocrati- } \\
\text { zação do país, o da batalha da anistia, autêntica batalha." (STF - Inteiro Teor do } \\
\text { Acórdão da ADPF } 153,2010 \text {, p. } 21 \text { ). }\end{array}$ \\
\hline Garantia & $\begin{array}{l}\text { "Toda a gente que conhece nossa História sabe que esse acordo político existiu, } \\
\text { resultando no texto da lei } 6.683 / 79 \text {. A procura dos sujeitos da História conduz à } \\
\text { incompreensão da História. É expressiva de uma visão abstrata, uma visão inti- } \\
\text { mista da História, que não se reduz a uma estática coleção de fatos desligados uns } \\
\text { dos outros. Os homens não podem fazê-la senão nos limites materiais da realida- } \\
\text { de." (STF - Inteiro Teor do Acórdão da ADPF } 153,2010, \text { p. } 21 \text { ). }\end{array}$ \\
\hline Apoio & $\begin{array}{l}\text { "[...] a formidável luta pela anistia é expressiva da página mais vibrante de resis- } \\
\text { tência e atividade democrática da nossa História. [...] Reduzir a nada essa luta [...] } \\
\text { é tripudiar sobre os que, com desassombro e coragem [...] lutaram pela anistia, } \\
\text { marco do fim do regime de exceção. [...] Essas jornadas, inesquecíveis, foram } \\
\text { heróicas. Não se as pode desprezar. A mim causaria espanto se a brava OAB [...], } \\
\text { denotadamente empenhada nessa luta, agora a desprezasse, em autêntico venire } \\
\text { contra factum proprium." (STF - Inteiro Teor do Acórdão da ADPF } 153,2010 \text {, } \\
\text { p. } 21-22 \text { ). Cita trechos de depoimento de Dalmo Dallari, corroborando o entendi- } \\
\text { mento da reciprocidade da anistia. }\end{array}$ \\
\hline Conclusão & $\begin{array}{l}\text { "Sem de qualquer modo negar o que diz a arguente ao proclamar que a dignidade } \\
\text { não tem preço [o que subscrevo], tenho que a indignidade que o cometimento } \\
\text { de qualquer crime expressa não pode ser retribuída com a proclamação de que } \\
\text { o instituto da anistia viola a dignidade humana. [...] O argumento descolado da } \\
\text { dignidade da pessoa humana para afirmar a invalidade da conexão criminal que } \\
\text { aproveitaria aos agentes políticos que praticaram crimes comuns contra oposito- } \\
\text { res políticos [...] não prospera." (STF - Inteiro Teor do Acórdão da ADPF 153, } \\
2010, \text { p. 24). }\end{array}$ \\
\hline
\end{tabular}

\subsubsection{O Conceito Específico de Crime Conexo}

\begin{tabular}{|c|l|}
\hline Dado & $\begin{array}{l}\text { "Tenho que a expressão ignora, no contexto da lei 6.683/79, o sentido ou os senti- } \\
\text { dos correntes, na doutrina, da chamada conexão criminal." (STF - Inteiro Teor do } \\
\text { Acórdão da ADPF 153, 2010, p. 26). }\end{array}$ \\
\hline \multirow{3}{*}{ Garantia } & $\begin{array}{l}\text { "Essa expressão, crimes conexos a crimes políticos, conota sentido a ser sindica- } \\
\text { do no momento histórico da sanção da lei. [...] A chamada Lei de Anistia diz com } \\
\text { uma conexão sui generis, própria ao momento histórico da transição para a demo- } \\
\text { cracia." (STF - Inteiro Teor do Acórdão da ADPF 153, 2010, p. 26). }\end{array}$ \\
\hline
\end{tabular}




\begin{tabular}{|c|l|}
\hline \multirow{3}{*}{ Apoio } & $\begin{array}{l}\text { “O } \S 1^{\circ} \text { do artigo } 1^{\circ} \text { da Lei } 6.683 / 79 \text { define crimes conexos aos crimes políticos } \\
\text { 'para os efeitos' desse artigo } 1^{\circ} \text {. São crimes conexos aos crimes políticos 'os cri- } \\
\text { mes de qualquer natureza relacionados com os crimes políticos ou praticados por } \\
\text { motivação política'.” (STF - Inteiro Teor do Acórdão da ADPF 153, 2010, p. 24). } \\
\text { Faz menção a diversos episódios em que foram promulgados decretos-leis que } \\
\text { anistiaram civis, militares, além de indivíduos que teriam praticado crimes cone- } \\
\text { xos a um determinado delito. Destaca, por fim, inúmeras decisões do Supremo } \\
\text { que evidenciam o caráter amplo das anistias. }\end{array}$ \\
\hline \multirow{3}{*}{ Conclusão } \\
$\begin{array}{l}\text { “A Arguente tem razão: o legislador procurou estender a conexão aos crimes pra- } \\
\text { ticados pelos agentes do Estado contra os que lutavam contra o Estado de exce- } \\
\text { ção. Daí o caráter bilateral da anistia, ampla e geral. Anistia que somente não foi } \\
\text { irrestrita porque não abrangia os já condenados - e com sentença transitada em } \\
\text { julgado [...] - pela prática de crimes de terrorismo, assalto, sequestro e atentado } \\
\text { pessoal.” (STF - Inteiro Teor do Acórdão da ADPF 153, 2010, p. 26-27). }\end{array}$ \\
\hline
\end{tabular}

\subsubsection{As Leis-medida}

\begin{tabular}{|c|c|}
\hline Dado & $\begin{array}{l}\text { "As leis-medida disciplinam diretamente determinados interesses, mostrando-se } \\
\text { imediatas e concretas. [...] são leis apenas em sentido formal, não o sendo, con- } \\
\text { tudo, em sentido material." (STF - Inteiro Teor do Acórdão da ADPF 153, 2010, } \\
\text { p. 31) }\end{array}$ \\
\hline Garantia & $\begin{array}{l}\text { "Pois, o que se impõe deixarmos bem vinculado é a inarredável necessidade de, } \\
\text { no caso de lei-medida, interpretar-se, em conjunto com o seu texto, a realidade no } \\
\text { e do momento histórico no qual ela foi editada, não a realidade atual." (STF - In- } \\
\text { teiro Teor do Acórdão da ADPF } 153,2010, \text { p. } 31 \text { ). }\end{array}$ \\
\hline Apoio & $\begin{array}{l}\text { "Registro a existência, no Brasil, de mais de trinta atos de anistia, veiculados pe- } \\
\text { los seguintes decretos ou leis-medida: [...]. [...] Como deveríamos hoje interpretar } \\
\text { esses textos? Tomando-se a realidade político-social do nosso tempo, nos dias de } \\
\text { hoje, ou aquelas no bojo das quais cada qual dessas anistias foi concedida?" (STF } \\
\text { - Inteiro Teor do Acórdão da ADPF 153, 2010, p. 32). Cita parecer e entrevista de } \\
\text { Sepúlveda Pertence*, para quem a amplitude do termo 'crimes conexos' "[...] ti- } \\
\text { nha o sentido indisfarçável de fazer compreender, no alcance da anistia, os delitos } \\
\text { de qualquer natureza cometidos 'nos porões do regime' [...] pelos agentes civis } \\
\text { e militares da repressão. [...] esse era o significado inequívoco do dispositivo." } \\
\text { (STF - Inteiro Teor do Acórdão da ADPF 153, 2010, p. 36). Anota, ainda, que a } \\
\text { Lei n. } 6.683 \text { precede tanto a Convenção da ONU contra a Tortura e Outros Tra- } \\
\text { tamentos ou Penas Cruéis, Desumanos ou Degradantes, quanto a Lei n. 9.455/97, } \\
\text { que define o crime de tortura. }\end{array}$ \\
\hline
\end{tabular}

* O parecer referido inúmeras vezes neste trabalho foi redigido em agosto de 1979, por José Paulo Sepúlveda Pertence, então Conselheiro da OAB. A entrevista, por sua vez, foi concedida à Revista Carta Maior, em 18 de janeiro de 2010. 


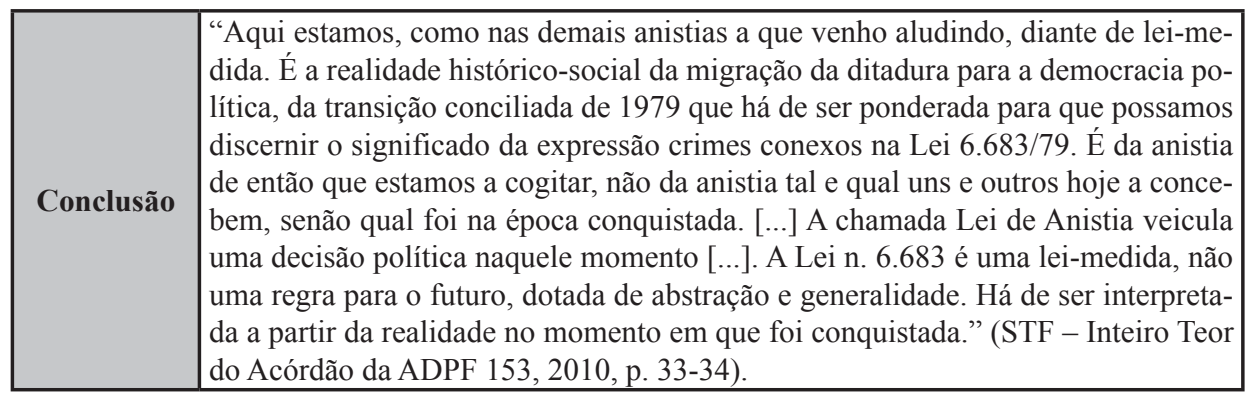

\subsubsection{A Competência do Legislativo}

\begin{tabular}{|c|l|}
\hline \multirow{5}{*}{ Dado } & $\begin{array}{l}\text { "No Estado democrático de direito o Poder Judiciário não está autorizado a alte- } \\
\text { rar, a dar outra redação [...] a texto normativo. Pode, a partir dele, produzir distin- } \\
\text { tas normas. Mas nem mesmo o Supremo Tribunal Federal está autorizado a rees- } \\
\text { crever leis de anistia." (STF - Inteiro Teor do Acórdão da ADPF 153, 2010, p. 38). }\end{array}$ \\
\hline \multirow{5}{*}{ Garantia } & \begin{tabular}{l} 
"Refiro-me a reiterados votos [...]. Nem mesmo para reparar flagrantes iniqui- \\
dades o Supremo pode avançar sobre a competência constitucional do Poder Le- \\
gislativo. Cabe bem lembrar, neste passo, trecho do voto do Ministro Orosimbo \\
Nonato [...]: 'Ao Poder Judiciário cabe apenas o encargo de interpretar a lei que \\
traduz a anistia, sua extensão e alcance quanto aos fatos e às pessoas. No que \\
tange ao mais, nada lhe cumpre fazer." (STF - Inteiro Teor do Acórdão da ADPF \\
Apoio \\
$\begin{array}{l}\text { "Revisão de lei de anistia, se mudanças do tempo e da sociedade a impuserem, } \\
\text { haverá - ou não - de ser feita pelo Poder Legislativo, não pelo Poder Judiciário." } \\
\text { (STF - Inteiro Teor do Acórdão da ADPF 153, 2010, p. 39). Nesse sentido, cita os } \\
\text { casos do Chile, Argentina e Uruguai. }\end{array}$ \\
\hline CDado que esse acordo [para permitir a transição do regime militar para o demo- \\
crático] resultou em um texto de lei, quem poderia revê-lo seria exclusivamente o \\
Poder Legislativo. Ao Supremo Tribunal Federal não incumbe alterar textos nor- \\
mativos concessivos de anistia." (STF - Inteiro Teor do Acórdão da ADPF 153, \\
2010, p. 39).
\end{tabular} \\
\hline
\end{tabular}

\subsubsection{A Emenda Constitucional 26/85}

\begin{tabular}{|c|l|}
\hline \multirow{2}{*}{ Dado } & $\begin{array}{l}\text { "Eis o que se deu: a anistia da lei de } 1979 \text { foi reafirmada, no texto da EC 26/85, } \\
\text { pelo poder constituinte da Constituição de 1988." (STF - Inteiro Teor do Acórdão } \\
\text { da ADPF 153, 2010, p. 43). }\end{array}$ \\
\hline Garantia & $\begin{array}{l}\text { "A Emenda Constitucional n. 26/85 inaugura a nova ordem constitucional. Con- } \\
\text { substancia a ruptura da ordem constitucional que decairá plenamente no advento } \\
\text { da Constituição [...] de 1988. Consubstancia, nesse sentido, a revolução branca } \\
\text { que a esta confere legitimidade." (STF - Inteiro Teor do Acórdão da ADPF 153, } \\
\text { 2010, p. 43). }\end{array}$ \\
\hline
\end{tabular}




\begin{tabular}{|c|l|}
\hline Apoio & Cita lições de Tércio Sampaio Ferraz Jr. e Nilo Batista. \\
\hline \multirow{3}{*}{ Conclusão } & $\begin{array}{l}\text { "[...] estão todos como que (re)anistiados pela Emenda, que abrange inclusive os } \\
\text { que foram condenados pela prática de crimes de terrorismo, assalto, sequestro e } \\
\text { atentado pessoal. Por isso não tem sentido questionar se a anistia [...] foi ou não } \\
\text { recebida pela Constituição de 1988. Pois a nova Constituição a (re)instaurou em } \\
\text { seu ato originário." (STF - Inteiro Teor do Acórdão da ADPF 153, 2010, p. 43- } \\
44) .\end{array}$ \\
\hline Condição de \\
Refutação \\
$\begin{array}{l}\text { "[...] somente se a nova constituição a tivesse afastado expressamente [a EC } \\
\text { Constituinte convocada por essa emenda constitucional produziu, a Constituição } \\
\text { de 1988. [...] Afirmada a integração da anistia de 1979 na nova ordem constitucio- } \\
\text { nal, teremos que sua adequação à Constituição de 1988 resulta inquestionável.” } \\
\text { (STF - Inteiro Teor do Acórdão da ADPF 153, 2010, p. 43-44). }\end{array}$ \\
\hline
\end{tabular}

\subsection{Ministra Carmen Lúcia}

A Ministra Carmen Lúcia, ao fim e ao cabo, irá acompanhar o entendimento do Ministro Relator, pela improcedência da ação. Para a Ministra, o sinal determinante da Lei n. 6.683/79 seria justamente o fato de esta representar o primeiro passo deflagrador do processo de participação da sociedade civil, em um período em que a liberdade desta era constantemente cerceada. Afirma: "E a sociedade falou altissonante sobre o projeto de lei, que se veio a converter na denominada Lei de Anistia [...], pela voz de sua então mais importante entidade, qual seja, a Ordem dos Advogados do Brasil [...]." (STF - Inteiro Teor do Acórdão da ADPF 153, 2010 , p. 81). O principal argumento trata da interpretação do dispositivo questionado.

\begin{tabular}{|c|l|}
\hline \multirow{5}{*}{ Dado } & $\begin{array}{l}\text { "A opção inicial do intérprete do } \S 1^{\circ} \text { do art. } 1^{\circ} \text { da Lei } 6.683 / 79 \text { haverá de ser } \\
\text { entre a adoção de elementos de inteligência da norma segundo os parâmetros atu- } \\
\text { ais, incluídos os princípios constitucionais vigentes [...], ou, diversamente, aco- } \\
\text { lher como elemento determinante para sua interpretação o quadro fático-histórico } \\
\text { no qual veio a ser criada e a finalidade nela patenteada." (STF - Inteiro Teor do } \\
\text { Acórdão da ADPF 153, 2010, p. 88). }\end{array}$ \\
\hline Garantia & $\begin{array}{l}\text { "Atualmente, a anistia decretada nas condições antes explicitadas [...] contraria o } \\
\text { sistema constitucional vigente [...]. Todavia, o exame mais aprofundado de todos } \\
\text { os elementos do que nos autos se contém impõe uma análise que [...] busque a } \\
\text { interpretação que conduza à aplicação efetiva e eficaz de todo o sistema constitu- } \\
\text { cional brasileiro, levando-se em consideração o momento político de transição do } \\
\text { regime autoritário para o democrático no qual foi promulgada a Lei de Anistia.” } \\
\text { (STF - Inteiro Teor do Acórdão da ADPF 153, 2010, p. 90). }\end{array}$ \\
\hline
\end{tabular}




\begin{tabular}{|c|l|}
\hline Apoio & $\begin{array}{l}\text { Cita Black, para quem "Uma lei deve ser interpretada em consonância com seu } \\
\text { espírito e razão [...]." (STF - Inteiro Teor do Acórdão da ADPF 153, 2010, p. 90) }\end{array}$ \\
\hline \multirow{3}{*}{ Conclusão "Se considerada uma interpretação normativa completamente alheia a) à história } \\
política brasileira na quadra em que ocorreu; b) à plena intenção legislativa então \\
determinante de sua elaboração [...]; c) ao espírito e à razão da Lei 6683/1979; \\
a presente Arguição de Descumprimento de Preceito Fundamental se converte- \\
ria numa espécie de "revisão criminal às avessas', instituída exclusivamente em \\
prejuízo de anistiados, na qual se superaria a realidade histórica e a eficácia de \\
uma lei vigente há mais de trinta anos ao se adotar certa linha exegética inovado- \\
ra quanto à compreensão da matéria." (STF - Inteiro Teor do Acórdão da ADPF \\
153, 2010, p. 90-91).
\end{tabular}

\subsection{Ministra Ellen Gracie}

A Ministra Ellen Gracie irá acompanhar o Ministro Relator no que diz respeito à conclusão de mérito. $\mathrm{O}$ argumento central de seu voto irá tratar do conceito de anistia.

\begin{tabular}{|c|l|}
\hline \multirow{5}{*}{ Dado } & $\begin{array}{l}\text { “Já o pedido alternativo de interpretação conforme que retirasse do âmbito de } \\
\text { abrangência da lei os atos praticados pelos agentes da repressão tampouco pode } \\
\text { ser atendido. Anistia é, em sua acepção grega, esquecimento, oblívio, desconsi- } \\
\text { deração intencional ou perdão de ofensas passadas. É superação do passado com } \\
\text { vistas à reconciliação de uma sociedade. E é, por isso mesmo, necessariamente } \\
\text { mútua." (STF - Inteiro Teor do Acórdão da ADPF 153, 2010, p. 152). }\end{array}$ \\
\hline Garantia & Cita Plutarco. \\
\hline Apoio & $\begin{array}{l}\text { Faz menção à digressão jurisprudencial feita pelo Ministro Eros Grau, quanto ao } \\
\text { entendimento do Supremo sobre o instituto da anistia e sua bilateralidade. Alude, } \\
\text { ainda, ao parecer de Sepúlveda Pertence e às lições de Dalmo Dallari. (STF - In- } \\
\text { teiro Teor do Acórdão da ADPF 153, 2010, p. 152). }\end{array}$ \\
\hline Conclusão & $\begin{array}{l}\text { "Não se faz transição, ao menos não se faz transição pacífica, entre um regime au- } \\
\text { toritário e uma democracia plena, sem concessões recíprocas. Por incômodo que } \\
\text { seja reconhecê-lo hoje, quando vivemos outro e mais virtuoso momento histórico, } \\
\text { a anistia, inclusive daqueles que cometeram crimes nos porões da ditadura, foi o } \\
\text { preço que a sociedade brasileira pagou para acelerar o processo pacífico de rede- } \\
\text { mocratização, com eleições livres e a retomada do poder pelos representantes da } \\
\text { sociedade civil.” (STF - Inteiro Teor do Acórdão da ADPF 153, 2010, p. 153). }\end{array}$ \\
\hline
\end{tabular}




\subsection{Ministro Marco Aurélio}

O Ministro Marco Aurélio, igualmente, segue o entendimento do Relator pela improcedência da ação. O argumento central que é apresentado refere-se ao conceito de anistia.

\begin{tabular}{|c|c|}
\hline Dado & $\begin{array}{l}\text { "[A Lei de Anistia] se trata, segundo Pontes de Miranda, de uma lei penal em } \\
\text { sentido inverso [...]. [...] a anistia é o apagamento do passado em termos de glo- } \\
\text { sa e responsabilidade [...]. [...] anistia é virada de página definitiva, é perdão em } \\
\text { sentido maior, desapego a paixões que nem sempre contribuem para o almejado } \\
\text { avanço cultural [...]. Anistia é ato abrangente de amor, sempre calcado na busca } \\
\text { do convívio pacífico dos cidadãos." (STF - Inteiro Teor do Acórdão da ADPF } \\
153,2010, \text { p. } 155) \text {. }\end{array}$ \\
\hline Garantia & $\begin{array}{l}\text { Cita as lições de Pontes de Miranda, o parecer de Sepúlveda Pertence e o Sermão } \\
\text { da Quinta-Feira da Quaresma, de Padre Vieira. }\end{array}$ \\
\hline Apoio & $\begin{array}{l}\text { "A Lei já começa com parágrafo abrangente, dos mais abrangentes [...]. Veio uma } \\
\text { definição toda própria de conexão - e o critério da especificidade prevalece, não } \\
\text { se podendo abrir a lei geral, o Código de Processo Penal, para saber o que é o } \\
\text { instituto [...]." (Ibidem, p. 156). Acrescenta que "[...] a atribuição do Congresso } \\
\text { Nacional, sob o ângulo da anistia, é política e não se submete, sob o ângulo da } \\
\text { oportunidade, da conveniência, da almejada justiça [...] a qualquer outro Poder." } \\
\text { (STF - Inteiro Teor do Acórdão da ADPF } 153,2010, \text { p. 154). }\end{array}$ \\
\hline Conclusão & 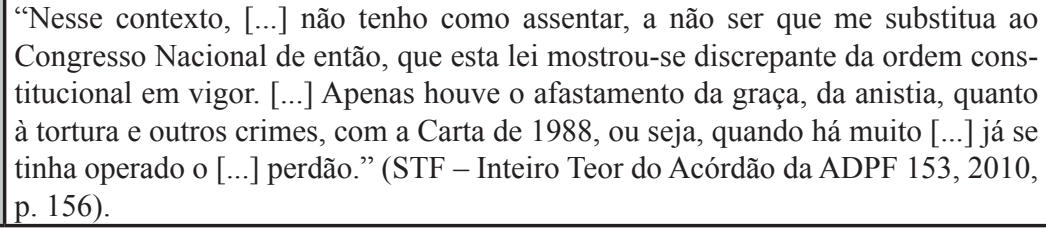 \\
\hline
\end{tabular}

\subsection{Ministro Celso de Mello}

O voto do Ministro Celso de Mello está em consonância com a conclusão do Relator da ADPF. É possível ver quais argumentos são trazidos para fundamentar este entendimento.

\subsubsection{A Legitimidade da Concessão da Anistia}

\begin{tabular}{|l|l|}
\hline \multirow{5}{*}{ Dado } & $\begin{array}{l}\text { "É certo, como sabemos, que o domínio no qual incidem, ordinariamente, as leis } \\
\text { concessivas da anistia é o dos ilícitos políticos. Nada obstava, contudo, que essa } \\
\text { expressiva manifestação da indulgência soberana do Estado abrangesse, também, } \\
\text { como era possível, então, sob a égide da Carta Federal de 1969, as infrações pe- } \\
\text { nais de direito comum." (STF - Inteiro Teor do Acórdão da ADPF 153, 2010, p. } \\
170) .\end{array}$ \\
\hline
\end{tabular}




\begin{tabular}{|c|c|}
\hline Garantia & $\begin{array}{l}\text { Cita a Carta Política de 1969. Faz referência, ainda, a vários doutrinadores para os } \\
\text { quais a concessão de anistia para delitos comuns seria admitida à época. }\end{array}$ \\
\hline Apoio & $\begin{array}{l}\text { "E foi com esse elevado propósito [de transição do regime autoritário para o } \\
\text { democrático] que se fez inequivocamente bilateral (e recíproca) a concessão da } \\
\text { anistia, com a finalidade de favorecer aqueles que [...] independentemente de sua } \\
\text { posição no arco ideológico, protagonizaram o processo político ao longo do re- } \\
\text { gime militar [...]." (Ibidem, p. 174). Reproduz trechos do parecer de Sepúlveda } \\
\text { Pertence, "que constitui clara atestação de que o objetivo da proposta submetida } \\
\text { a amplo debate nacional era, sem qualquer dúvida, o de beneficiar tanto os adver- } \\
\text { sários do regime castrense quanto os agentes incumbidos da repressão [...]." (STF } \\
\text { - Inteiro Teor do Acórdão da ADPF } 153,2010 \text {, p. 170). Explicita alguns excertos } \\
\text { de debates parlamentares que reconhecem a bilateralidade da anistia. }\end{array}$ \\
\hline Conclusão & $\begin{array}{l}\text { "Isso significa que se revestiu de plena legitimidade jurídico-constitucional a } \\
\text { opção legislativa do Congresso Nacional que }[\ldots] \text { culminou por abranger, com a } \\
\text { outorga da anistia, não só os delitos políticos, mas, também, os crimes a estes } \\
\text { conexos e }[\ldots] \text { aqueles }[\ldots] \text { relacionados a atos de delinquência política ou cuja } \\
\text { prática decorreu de motivação política." (STF - Inteiro Teor do Acórdão da ADPF } \\
153,2010, \text { p. 173). }\end{array}$ \\
\hline $\begin{array}{c}\text { Acréscimo } \\
\text { Retórico }\end{array}$ & $\begin{array}{l}\text { "É preciso ressaltar [...] que a lei de anistia brasileira, exatamente por seu caráter } \\
\text { bilateral, não pode ser qualificada como uma lei de autoanistia, o que torna incon- } \\
\text { sistente, para os fins desse julgamento a invocação dos mencionados precedentes } \\
\text { da Corte Interamericana de Direitos Humanos. [...] É tão intensa a intangibilidade } \\
\text { de uma lei de anistia [...], que, uma vez editada, [...] os efeitos jurídicos que dela } \\
\text { emanam não podem ser suprimidos por legislação superveniente [...]." (STF - In- } \\
\text { teiro Teor do Acórdão da ADPF } 153,2010, \text { p. 184-186). }\end{array}$ \\
\hline
\end{tabular}

\subsubsection{A Prescrição Penal}

\begin{tabular}{|c|l|}
\hline \multirow{3}{*}{ Dado } & $\begin{array}{l}\text { "[...] a pretensão punitiva do Estado, caso acolhida a postulação deduzida pela } \\
\text { parte ora arguente, achar-se-ia atingida pela prescrição penal, calculada esta pelo } \\
\text { prazo mais longo (20 anos) previsto em nosso ordenamento positivo." (STF - In- } \\
\text { teiro Teor do Acórdão da ADPF 153, 2010, p. 189). }\end{array}$ \\
\hline \multirow{3}{*}{ Garantia } & $\begin{array}{l}\text { "Nem se sustente [...] que a imprescritibilidade penal, na espécie ora em exame, } \\
\text { teria por fundamento a 'Convenção sobre a Imprescritibilidade dos Crimes de } \\
\text { Guerra e dos Crimes contra a Humanidade'. [...] como se sabe, essa Convenção } \\
\text { das Nações Unidas [...] jamais foi subscrita pelo Brasil [...]." (STF - Inteiro Teor } \\
\text { do Acórdão da ADPF 153, 2010, p. 189-190). }\end{array}$ \\
\hline \multirow{5}{*}{ Apoio } & $\begin{array}{l}\text { "Ninguém pode ignorar que, em matéria penal, prevalece, sempre, o postulado } \\
\text { da reserva constitucional de lei em sentido formal. Esse princípio, além de consa- } \\
\text { grado em nosso ordenamento [...] também encontra expresso reconhecimento na } \\
\text { Convenção Americana de Direitos Humanos [...] e no Pacto Internacional sobre } \\
\text { Direitos Civis e Políticos [...]. [...] o tema da prescrição subsume-se ao âmbito } \\
\text { das normas de direito material, de natureza eminentemente penal, regendo-se, em } \\
\text { consequência, pelo postulado da reserva do Parlamento, como adverte autorizado } \\
\text { magistério doutrinário [...]." (STF - Inteiro Teor do Acórdão da ADPF 153, 2010, } \\
\text { p. 190-192). }\end{array}$ \\
\hline
\end{tabular}




\begin{tabular}{|c|l|}
\hline Conclusão & $\begin{array}{l}\text { Conclui dizendo que, além de a pretensão punitiva do Estado frente a esses cri- } \\
\text { mes já estar prescrita, somente lei interna poderia qualificar-se, constitucional- } \\
\text { mente, como fonte formal legitimadora da normativa concernente à prescrição } \\
\text { penal ((STF - Inteiro Teor do Acórdão da ADPF 153, 2010, p. 192) }\end{array}$ \\
\hline Condição de & $\begin{array}{l}\text { “[...] mantida íntegra a Lei de Anistia de 1979, produziu ela [...] todos os efeitos } \\
\text { que lhe eram inerentes, de tal modo que, ainda que considerada incompatível com } \\
\text { Refutação } \\
\text { Cacial desde o instante mesmo em que veio a lume.” (STF - Inteiro Teor do Acór- } \\
\text { dão da ADPF 153, 2010, p. 197). }\end{array}$ \\
\hline
\end{tabular}

\subsection{Ministro Cezar Peluso}

O voto do Ministro Peluso vem estruturado em torno do argumento do conceito de conexão criminal. Antes de concluir, julgando pela improcedência da ação, afirma que a pretensão da autora é absolutamente estéril, em razão de ter sido atingida pela prescrição penal. Para o Ministro, todas as ações criminais e cíveis - com exceção das declaratórias -, já estariam prescritas. Sustenta que, em nosso sistema, qualquer lei que revogasse os efeitos da anistia seria, inequivocamente, lei mais gravosa, que não poderia retroagir de maneira alguma - até mesmo porque, tratando-se de lei de anistia, já teria exaurido seus efeitos no momento em que incidiu.

\begin{tabular}{|c|l|}
\hline \multirow{3}{*}{ Dado } & $\begin{array}{l}\text { "[...] essa lei contém uma definição particular [...] para efeito da sua própria inci- } \\
\text { dência e aplicação. Noutras palavras, ela própria define o que deva, no seu con- } \\
\text { texto, ser entendido como crimes conexos." (STF - Inteiro Teor do Acórdão da } \\
\text { ADPF 153, 2010, p. 204). }\end{array}$ \\
\hline \multirow{5}{*}{ Garantia } & $\begin{array}{l}\text { "Ora, evidentissimamente, o caso não cuida de conexão nesse sentido tradicio- } \\
\text { nal e técnico-jurídico [do Código de Processo Penal]. A conexão aqui pressuposta } \\
\text { tem outro sentido, é o sentido que chamo de metajurídico." (STF - Inteiro Teor do } \\
\text { Acórdão da ADPF 153, 2010, p. 205). }\end{array}$ \\
\hline \multirow{5}{*}{ Apoio } & $\begin{array}{l}\text { "E há, desde logo, dois elementos que corroboram esta afirmação. O primeiro é } \\
\text { de que não se trata de uso inédito da expressão. [...] é da tradição normativa bra- } \\
\text { sileira, em tema de concessão de anistia, mediante vários decretos, usar precisa- } \\
\text { mente a expressão crimes conexos [...]. O segundo, [...] [p]orque, a entender-se } \\
\text { aqui conexão como fenômeno puramente processual, ela só se aplicaria aos casos } \\
\text { de concurso de crimes e de concurso de pessoal. Ou seja, [...] só para um dos la- } \\
\text { dos haveria a anistia, que seria muito mais restrita do que é, perdendo, assim todo } \\
\text { o seu significado histórico na transição para um regime democrático. Depois, } \\
\text { quando a lei faz referência à relação de conexão, usa de uma categoria de ordem } \\
\text { política [...]." (STF - Inteiro Teor do Acórdão da ADPF 153, 2010, p. 205-206). }\end{array}$ \\
\hline
\end{tabular}




\begin{tabular}{|c|l|}
\hline \multirow{3}{*}{ Conclusão } & $\begin{array}{l}\text { "A amplitude da norma é, portanto, óbvia, enquanto transcende o campo dos cri- } \\
\text { mes políticos em sentido estrito ou em sentido figurado, como aqueles praticados } \\
\text { com motivação política, ao abranger crimes de qualquer ordem. Foi este o sentido } \\
\text { que o parecer [e] [...] a entrevista do Ministro Sepúlveda Pertence [...] reconhe- } \\
\text { ceram em outras palavras [...]." (STF - Inteiro Teor do Acórdão da ADPF 153, } \\
\text { 2010, p. 206). }\end{array}$ \\
\hline Acréscimo \\
Retórico & $\begin{array}{l}\text { "E a mesma lei podia operar essa extensão. E fê-lo de modo textual, ao relacio- } \\
\text { narpoca, não havia, como hoje há, nenhum obstáculo de ordem constitucional nem } \\
\text { legal para que o legislador estendesse a anistia aos crimes de qualquer natureza." } \\
\text { (STF - Inteiro Teor do Acórdão da ADPF 153, 2010, p. 206-207). }\end{array}$ \\
\hline
\end{tabular}

\subsection{Ministro Gilmar Mendes}

O Ministro Gilmar Mendes inicia seu voto suscitando o conceito de anistia: “[...] a anistia é ato revestido de caráter eminentemente político e sua amplitude é definida de forma política." (STF - Inteiro Teor do Acórdão da ADPF 153, 2010, p. 234). A anistia ampla e geral, segundo o Ministro, resultou de um compromisso constitucional que tornou possível a fundação e construção da ordem constitucional de 1988. Arremata o voto seguindo o entendimento do Relator, pela improcedência da ação.

\subsubsection{A Anistia Ampla e Geral}

\begin{tabular}{|c|l|}
\hline \multirow{5}{*}{ Dado } & $\begin{array}{l}\text { “A anistia ampla e geral, insculpida na lei 6683/1979, é abrangente o bastante } \\
\text { para abarcar todas as posições político-ideológicas existentes na contraposição } \\
\text { amigo/inimigo estabelecidas no regime político precedente, não havendo qual- } \\
\text { quer incompatibilidade da sua amplitude, ínsita ao parágrafo primeiro do artigo } \\
\text { primeiro, com a constituição pactuada de 1988." (STF - Inteiro Teor do Acórdão } \\
\text { da ADPF 153, 2010, p. 243). }\end{array}$ \\
\hline \multirow{5}{*}{ Garantia } & $\begin{array}{l}\text { "E, no que se refere à amplitude da anistia concedida pela Lei 6.683/79, ressalte- } \\
\text {-se que o próprio arguente sustentou ativamente e zelou pela amplíssima abran- } \\
\text { gência, à época das discussões legislativas." (STF - Inteiro Teor do Acórdão da } \\
\text { ADPF 153, 2010, p. 243). }\end{array}$ \\
\hline Apoio & $\begin{array}{l}\text { Cita parecer e entrevista de Sepúlveda Pertence, e também o parecer de Sergio } \\
\text { Tostes, aprovado pelo IAB (Instituto dos Advogados Brasileiros) em 1979. "Esse } \\
\text { verdadeiro depoimento de 'testemunha privilegiada' [referindo-se à entrevis- } \\
\text { ta de Pertence] expõe com precisão a abrangência da anistia concedida pela lei } \\
\text { 6683/1979.” (STF - Inteiro Teor do Acórdão da ADPF 153, 2010, p. 249). }\end{array}$ \\
\hline \multirow{2}{*}{ Conclusão } & $\begin{array}{l}\text { "[...] a amplitude do processo de anistia é ínsita ao conteúdo pactual do próprio } \\
\text { texto, não se afigurando incompatível com a ordem constitucional vigente.” (STF } \\
\text { - Inteiro Teor do Acórdão da ADPF 153, 2010, p. 243). }\end{array}$ \\
\hline
\end{tabular}




\begin{tabular}{|c|l|}
\hline \multirow{3}{*}{ Acréscimo } & $\begin{array}{l}\text { "Na lição de Aníbal Bruno, a anistia é a forma de indulgência estatal mais enér- } \\
\text { gica e de mais amplas consequências jurídicas [...]. Daí que, 'uma vez concedida, } \\
\text { não pode ser revogada. [...] Aqui faço um parêntese para ressaltar que não tem } \\
\text { Retórico }\end{array}$ \\
$\begin{array}{l}\text { curso a tese [...] da imprescritibilidade em razão dos tratados que vieram a ser } \\
\text { subscritos posteriormente. [...] se houver alguma alteração para tornar os crimes } \\
\text { imprescritíveis [...], ela não se aplica aos crimes já praticados. Nós temos uma } \\
\text { farta jurisprudência a propósito desse tema." (STF - Inteiro Teor do Acórdão da } \\
\text { ADPF 153,2010, p. 249-251). }\end{array}$ \\
\hline
\end{tabular}

\subsubsection{A Emenda Constitucional 26/85}

\begin{tabular}{|c|c|}
\hline Dado & $\begin{array}{l}\text { "[...] parte dessa desejada ampliação da anistia vai se consumar [...] com a emen- } \\
\text { da 26/1985." (STF - Inteiro Teor do Acórdão da ADPF 153, 2010, p. 251). }\end{array}$ \\
\hline Garantia & $\begin{array}{l}\text { "Nesse contexto, não se pode olvidar que a EC } 26 \text {, de } 1985 \text {, que convocou a As- } \\
\text { sembleia Nacional Constituinte e deu início ao processo constituinte, incorporou } \\
\text { a anistia, expressamente em seu art. } 4^{\circ} \text {, como um dos pressupostos de possibili- } \\
\text { dade da construção da nova ordem constitucional. [...] [A EC 26/85] traz as novas } \\
\text { bases para a construção de outra ordem constitucional." (STF - Inteiro Teor do } \\
\text { Acórdão da ADPF } 153,2010, \text { p., 252-254). }\end{array}$ \\
\hline Apoio & $\begin{array}{l}\text { Após uma extensa apresentação de doutrina (Carl Schmitt, Otto-Brun Bryde, } \\
\text { Konrad Hesse) e jurisprudência, afirma "[...] o princípio da imutabilidade das } \\
\text { cláusulas pétreas se estende, fundamentalmente, às suas próprias disposições e } \\
\text { ao processo de revisão constitucional. [...] É possível, pois, proceder-se à tran- } \\
\text { sição de uma constituição para outra em um processo ordenado e sem quebra da } \\
\text { legitimidade." (STF - Inteiro Teor do Acórdão da ADPF 153, 2010, p. 261). Con- } \\
\text { tinua o raciocínio, dizendo: "Se se entendesse [...] que a revisão total ou a revisão } \\
\text { parcial das cláusulas pétreas está implícita na própria constituição, poder-se-ia } \\
\text { cogitar [...] até mesmo de alteração das disposições constitucionais referentes ao } \\
\text { processo de emenda constitucional com o escopo de explicitar a ideia de revisão } \\
\text { total ou de revisão específica das cláusulas pétreas, permitindo, assim, que se dis- } \\
\text { ciplinasse, juridicamente, a alteração das clausulas pétreas ou mesma a substitui- } \\
\text { ção ou superação da ordem constitucional vigente por outra." (STF - Inteiro Teor } \\
\text { do Acórdão da ADPF } 153,2010, \text { p. 263). }\end{array}$ \\
\hline Conclusão & $\begin{array}{l}\text { "A EC } 26 / 85 \text { muito se aproxima de um modelo de revisão total instaurado pela } \\
\text { própria ordem constitucional, sem maiores rupturas do ponto de vista histórico- } \\
\text {-político. Devemos refletir, então, sobre a própria legitimidade constitucional de } \\
\text { qualquer ato tendente a revisar ou restringir a anistia incorporada à EC } 26 / 85 \text {. } \\
\text { Parece certo que estamos, dessa forma, diante de uma hipótese na qual estão em } \\
\text { jogo os próprios fundamentos de nossa ordem constitucional. Enfim, a EC } 26 / 85 \\
\text { incorporou a anistia como um dos fundamentos da nova ordem constitucional que } \\
\text { se construía à época, fato que torna praticamente impensável qualquer modifi- } \\
\text { cação de seus contornos originais que não repercuta nas próprias bases de nossa } \\
\text { Constituição, e, portanto, de toda a vida político-institucional pós-1988." (STF - } \\
\text { Inteiro Teor do Acórdão da ADPF } 153,2010, \text { p. 264). }\end{array}$ \\
\hline
\end{tabular}


Condição de Refutação
"Todavia, este Supremo Tribunal Federal firmou entendimento no sentido de que não cabe sequer revisão criminal quando se basear a pretensão em mudança de interpretação da lei, pelo que não haveria consequências para os fins buscados [...]." (STF - Inteiro Teor do Acórdão da ADPF 153, 2010, p. 91).

\subsection{Ministro Ricardo Lewandowski}

O Ministro Lewandowski inicia seu voto de maneira marcante. Afirma:

De fato, a Lei de Anistia, longe de ter sido outorgada dentro de um contexto de concessões mútuas e obedecendo a uma espécie de 'acordo tácito', celebrado não se sabe bem ao certo por quem, ela em verdade foi editada em meio a um clima de crescente insatisfação popular contra o regime autoritário. (STF - Inteiro Teor do Acórdão da ADPF 153, 2010, p. 107)

\section{É possível observar como se dá a construção dos argumentos neste} voto.

\subsubsection{A Interpretação do Preceito Impugnado}

\begin{tabular}{|c|c|}
\hline Dado & $\begin{array}{l}\text { "[...] a magna tarefa de interpretar o preceito legal aqui contestado exige que se } \\
\text { ultrapasse a nebulosa indagação acerca da voluntas legislatoris }[\ldots] \text { e se passe a } \\
\text { examinar a voluntas legis, cuja avaliação se faz a partir de critérios hermenêuticos } \\
\text { mais objetivos. Verifico, assim, que a atecnia, proposital ou involuntária [...] da } \\
\text { redação do } \S 1^{\circ} \text { do art. } 1^{\circ} \text { da Lei } 6.683 / 79 \text {, no ponto em que alude à conexão entre } \\
\text { crimes comuns e políticos [...] vem causando, por sua inegável equivocidade, des- } \\
\text { de quando veio a lume, considerável perplexidade dentre aqueles que buscaram } \\
\text { interpretá-lo." (STF - Inteiro Teor do Acórdão da ADPF } 153,2010 \text {, p. 110). }\end{array}$ \\
\hline Garantia & $\begin{array}{l}\text { "Ora, como se sabe, o sistema penal e processual brasileiro somente contempla as } \\
\text { seguintes hipóteses de conexão: [material; intersubjetiva por simultaneidade; in- } \\
\text { tersubjetiva por concurso; objetiva; probatória; intersubjetiva por reciprocidade]." } \\
\text { (STF - Inteiro Teor do Acórdão da ADPF } 153,2010, \text { p. 110-111). }\end{array}$ \\
\hline Apoio & $\begin{array}{l}\text { "A simples menção à conexão no texto legal contestado, à toda evidência, não tem } \\
\text { o condão de estabelecer um vínculo de caráter material entre os crimes políticos } \\
\text { cometidos pelos opositores do regime e os delitos comuns atribuídos aos agentes } \\
\text { do Estado, para o fim de lhes conferir o mesmo tratamento jurídico.” (STF - In- } \\
\text { teiro Teor do Acórdão da ADPF } 153,2010, \text { p. 112). Cita alguns julgados. }\end{array}$ \\
\hline
\end{tabular}




\begin{tabular}{|c|l|}
\hline \multirow{5}{*}{ Conclusão } & $\begin{array}{l}\text { "Destarte, embora o legislador de } 1979 \text { tenha pretendido caracterizar, para o } \\
\text { efeito da anistia, a conexão material entre ilícitos de natureza distinta [...], com } \\
\text { o objetivo de ensejar a absorção das condutas delituosas comuns pelos crimes } \\
\text { políticos, não é difícil constatar que tal desiderato, ao menos do ponto de vista } \\
\text { técnico-jurídico, não logrou ser bem sucedido." (STF - Inteiro Teor do Acórdão } \\
\text { da ADPF 153, 2010, p. 112). Não seria possível estabelecer tal conexão material } \\
\text { entre os ilícitos políticos e comuns pelo fato de não haver nexo teleológico, con- } \\
\text { sequencial ou ocasional exigido pela doutrina para sua caracterização. }\end{array}$ \\
\hline Condição de \\
Refutação & $\begin{array}{l}\text { "Todavia, este Supremo Tribunal Federal firmou entendimento no sentido de que } \\
\text { não cabe sequer revisão criminal quando se basear a pretensão em mudança de in- } \\
\text { terpretação da lei, pelo que não haveria consequências para os fins buscados [...]." } \\
\text { (STF - Inteiro Teor do Acórdão da ADPF 153, 2010, p. 91). }\end{array}$ \\
\hline
\end{tabular}

\subsubsection{A Distinção entre Crimes Comuns e Crimes Políticos}

\begin{tabular}{|c|c|}
\hline Dado & $\begin{array}{l}\text { "Como se vê, o [STF] vem fazendo uma clara distinção entre crimes políticos típi- } \\
\text { cos }[\ldots] \text {, praticados }[\ldots] \text { contra a integridade territorial de um país, a pessoa de seus } \\
\text { governantes, a soberania nacional, o regime representativo e democrático ou o Es- } \\
\text { tado de Direito, e crimes políticos relativos [...], com relação aos quais [...] cumpre } \\
\text { fazer uma abordagem caso-a-caso [...]. Essa abordagem, na jurisprudência da Corte, } \\
\text { deve guiar-se por dois critérios, a saber: (i) o da preponderância e (ii) o da atrocida- } \\
\text { de dos meios." (STF - Inteiro Teor do Acórdão da ADPF } 153,2010, \text { p. 126) }\end{array}$ \\
\hline Garantia & $\begin{array}{l}\text { Sobre a distinção traçada anteriormente, o Ministro cita uma série de julgados do } \\
\text { STF - sobretudo os que tratam de extradições. }\end{array}$ \\
\hline Apoio & $\begin{array}{l}\text { Assevera o Ministro que, de acordo com estudiosos do assunto, vários seriam os } \\
\text { delitos comuns que poderiam ter sido praticados por agentes do Estado durante o } \\
\text { regime militar, todos tipificados no Código Penal de } 1940 \text { (STF - Inteiro Teor do } \\
\text { Acórdão da ADPF } 153,2010 \text {, p. 116-117) e, em sua maioria, reproduzidos nos } \\
\text { Códigos Penais Militares de } 1944 \text { e } 1971 \text {. O mesmo ocorre com o delito de tortu- } \\
\text { ra, que jamais foi tolerado pelo ordenamento jurídico republicano. }\end{array}$ \\
\hline Conclusão & $\begin{array}{l}\text { "Ora, como a lei de anistia não cogita de crimes comuns, e emprega, de forma } \\
\text { tecnicamente equivocada, o conceito de conexão, segue-se que a possibilidade de } \\
\text { abertura de persecução penal contra os agentes do Estado que tenham eventual- } \\
\text { mente cometido os delitos capitulados na legislação penal ordinária pode, sim, } \\
\text { ser desencadeada, desde que se descarte, caso a caso, a prática de um delito de } \\
\text { natureza política ou cometido por motivação política, mediante a aplicação dos } \\
\text { critérios acima referidos." (STF - Inteiro Teor do Acórdão da ADPF 153, 2010, } \\
\text { p. 126-127). }\end{array}$ \\
\hline $\begin{array}{l}\text { Condição de } \\
\text { Refutação }\end{array}$ & $\begin{array}{l}\text { "Por essa razão, inclusive, afigura-se irrelevante que a Lei } 6.683 / 1979 \text { [...] tenha } \\
\text { sido, mais tarde, parcialmente reproduzida na EC } 26 / 1985 \text {. Primeiro, porque, teo- } \\
\text { ricamente, uma lei de anistia surte efeitos imediatos [...]. Depois, porque os vícios } \\
\text { que tisnavam o primeiro diploma legal persistiram integralmente no segundo [...]. } \\
\text { Por fim, porque a Constituição de } 1988 \text {, embora pudesse fazê-lo, não ratificou a } \\
\text { tal anistia, preferindo concedê-la, em outros termos, para beneficiários distintos, no } \\
\text { Art. } 8^{\circ} \text { do [ADCT]." (STF - Inteiro Teor do Acórdão da ADPF 153, 2010, p. 127). }\end{array}$ \\
\hline
\end{tabular}


Na seção dispositiva do voto, julga a ADPF parcialmente procedente, para dar interpretação conforme ao $\S 1^{\circ}$ do artigo $1^{\circ}$ da Lei n. 6.683/79. Com isso, os agentes do Estado não estariam automaticamente abrangidos pela anistia concedida, porém, antes de ser admitida a persecução penal contra aqueles agentes, deveria ser realizada uma abordagem caso a caso, mediante os critérios da preponderância e da atrocidade dos meios, para averiguar se houve o cometimento de crimes comuns, ou de delitos políticos que poderiam ser considerados conexos.

\subsection{Ministro Ayres Britto}

O Ministro Ayres Britto também inicia seu voto de maneira insigne. Afirma que a anistia é um perdão coletivo de quem incidiu em certas práticas criminosas.

E, para a coletividade perdoar certos infratores, é preciso que o faça por modo claro, assumido, autêntico, não incidindo jamais em tergiversação redacional, em prestidigitação normativa, para não dizer em hipocrisia normativa. (STF - Inteiro Teor do Acórdão da ADPF 153,2010, p. 135-136)

O argumento central do voto do Ministro aborda a questão da interpretação da Lei de Anistia.

\begin{tabular}{|c|l|}
\hline \multirow{5}{*}{ Dado } & $\begin{array}{l}\text { "E o fato é que, com todas as vênias [...] eu não consigo enxergar no texto da lei } \\
\text { de anistia essa clareza que outros enxergam, com tanta facilidade, no sentido de } \\
\text { que ela [...] sem dúvida incluiu no seu âmbito pessoal de incidência todas as pes- } \\
\text { soas que cometeram crimes, não só os singelamente comuns, mas os caracteris- } \\
\text { ticamente hediondos ou assemelhados, desde que sob motivação política ou sob } \\
\text { tipificação política." (STF - Inteiro Teor do Acórdão da ADPF 153, 2010, p. 136). } \\
\text { Reitera a dicotomia entre crimes absolutamente políticos, e crimes relativamente } \\
\text { políticos - que são crimes comuns, porém com alguma motivação política. }\end{array}$ \\
\hline \multirow{6}{*}{ Garantia } & $\begin{array}{l}\text { "[...] o chamado 'método histórico' de interpretação, em rigor, não é um método. } \\
\text { É um paramétodo de interpretação jurídica, pois a ele só se deve recorrer quan- } \\
\text { do subsiste alguma dúvida de intelecção quanto à vontade normativa do texto in- } \\
\text { terpretado. [...] Ou seja, o método histórico não é para afastar a priori qualquer } \\
\text { dúvida [...]. E para tirar dúvida por acaso remanescente da aplicação dos outros } \\
\text { métodos de interpretação. E, nesse caso da Lei de Anistia, eu não tenho nenhuma } \\
\text { dúvida de que os crimes hediondos e equiparados não foram incluídos no chama- } \\
\text { do núcleo deôntico da lei." (STF - Inteiro Teor do Acórdão da ADPF 153, 2010, } \\
\text { p. 137). }\end{array}$ \\
\hline
\end{tabular}




\begin{tabular}{|c|c|}
\hline Apoio & $\begin{array}{l}\text { "O que interessa é a vontade objetiva da lei, não é a vontade subjetiva do legisla- } \\
\text { dor. [...] Então, vou ler a Lei [...]. [...] o parâmetro, o centro de referibilidade ina- } \\
\text { fastável é o crime político. O conexo é secundário [...]; no plano da principalidade } \\
\text { está o político, que tem que ser o crime praticado com essa motivação [...]. O que, } \\
\text { a priori, excluiria todo tipo de crime de sangue com resultado morte, crime de } \\
\text { lesa-humanidade, praticado por uma antipessoa." (STF - Inteiro Teor do Acórdão } \\
\text { da ADPF } 153,2010, \text { p. } 140-141) \text {. }\end{array}$ \\
\hline Conclusão & $\begin{array}{l}\text { "Então, peço vênia aos que pensam diferentemente, e digo, com todo o respeito: } \\
\text { eu não consigo enxergar, na vontade objetiva desses dispositivos conjugados, o } \\
\text { caráter amplo, geral e irrestrito que se busca emprestar à lei de anistia." (STF - } \\
\text { Inteiro Teor do Acórdão da ADPF } 153,2010, \text { p. 144). }\end{array}$ \\
\hline $\begin{array}{l}\text { Acréscimo } \\
\text { Retórico }\end{array}$ & $\begin{array}{l}\text { A prova de que a anistia não teria sido nem ampla, nem geral, tampouco irrestri- } \\
\text { ta, estaria na EC } 26 / 85 \text {. Tal Emenda teria promovido uma relativização, especial- } \\
\text { mente em seu artigo } 4^{\circ} \text {, que concedeu anistia a todos os servidores públicos civis } \\
\text { da Administração direta e indireta e militares, punidos por atos de exceção, insti- } \\
\text { tucionais ou complementares. Afirma o Min. Ayres, aqueles "punidos por efeito } \\
\text { dos atos institucionais e complementares, e não aqueles que estavam a serviço do } \\
\text { regime de exceção." (STF - Inteiro Teor do Acórdão da ADPF } 153,2010 \text {, p. 143). } \\
\text { A Constituição também teria relativizado a anistia no ADCT, artigo } 8^{\circ} \text {. }\end{array}$ \\
\hline
\end{tabular}

O Ministro Ayres Britto encerra seu voto julgando parcialmente procedente a ADPF 153 , para excluir do $\S 1^{\circ}$ do artigo $1^{\circ}$ da Lei 6.683/79 qualquer interpretação que signifique estender a anistia aos crimes previstos no inciso XLIII do artigo $5^{\circ}$ da Constituição - os crimes hediondos e os que lhe sejam equiparados: homicídio, tortura e estupro, especialmente.

\section{Conclusões}

A partir da análise sistematizada no tópico anterior, é possível examinar os argumentos interpretativos que compõem a decisão proferida na ADPF 153, dividindo-os em algumas categorias, propostas por Neil MacCormick: linguísticos, sistêmicos e teleológico-avaliativos.

Os argumentos linguísticos são aqueles que fazem menção ao "sentido claro" de palavras ou conceitos usados na linguagem. Isto é, esses argumentos pressupõem um recurso ao contexto linguístico como fonte de razões para optar por uma determinada interpretação, em detrimento de outra. Na decisão da ADPF 153, são frequentes as referências à doutrina ou à jurisprudência dominante para conceituar alguns termos, como anistia, conexão, crimes comuns, crimes políticos etc. 
Há, também, os argumentos sistêmicos, para os quais o sistema jurídico seria o contexto especial de um texto. Ou seja, a busca pelo melhor sentido de uma norma deveria ser empreendida dentro de sua própria conjuntura. "A parte faz sentido no contexto do todo, e a lei é um elemento dentro do sistema jurídico como um todo." - assevera MacCormick (2008, p. 169-170). O autor enumera uma série de argumentos que comporiam o conceito mais amplo de argumentos sistêmicos. De maneira sucinta, seriam eles: harmonização contextual, argumentos a partir de precedentes, de argumentos por analogia, conceituais, argumentos a partir de princípios gerais de direito e a partir da história.

Pode-se fornecer breves explicações sobre cada um destes argumentos: i) harmonização contextual: o "esquema jurídico mais amplo" de uma disposição legal - a lei em sua íntegra e o conjunto de leis que se mostra pertinente para aquela matéria; ii) argumentos a partir de precedentes: a consonância com o entendimento dado anteriormente pelas Cortes. Evidentemente, o peso que é dado a um precedente da força deste no sistema jurídico - vinculante ou meramente persuasiva; iii) argumentos por analogia: se uma disposição legal é significativamente análoga a uma disposição similar, este seria um bom fundamento para justificar um entendimento que se orienta no sentido de seguir essa analogia; iv) argumentos conceituais: o conceito jurídico é interpretado de maneira a manter o uso consistente do conceito por todo o sistema jurídico; v) argumentos a partir de princípios gerais de direito: se qualquer princípio geral de direito for aplicável à matéria de que trata uma disposição legal, deve-se favorecer e interpretação que esteja em maior conformidade com o princípio em questão; vi) argumentos a partir da história: uma lei ou grupo de leis podem, ao longo do tempo, ser interpretados segundo uma compreensão historicamente desenvolvida sobre o propósito ou teor da lei, ou do grupo de leis como um todo. Assim, em um caso concreto, a interpretação poderia ser compatível com aquela compreensão historicamente desenvolvida.

Em um caso como o da ADPF 153, ver-se-á que os argumentos sistêmicos se revestem de especial importância, na medida em que chamam a atenção para a coerência geral, como um ideal que governa a visão sobre o sistema jurídico e, com isso, dá peso à abordagem interpretativa favorecida pelos vários tipos de argumentos sistêmicos. (MACCORMICK, 
2008, p. 175). Conforme será discutido mais adiante, não é desarrazoado questionar até que ponto a interpretação que o Supremo Tribunal Federal confere à Lei de Anistia entra em consonância com tal ideal de coerência do sistema do direito.

Por fim, há os argumentos teleológico-avaliativos que seriam os argumentos que miram os objetivos ou finalidades de um texto, a fim de obter a interpretação que se coaduna com tais desígnios. Para esses argumentos, a legislação seria uma atividade não apenas racional, mas também teleológica, guiada por programas políticos estruturados, e atrelada a um senso de justiça e bem comum. A intenção a que tais argumentos se referem é, claramente, a intenção das leis, tomadas em conjunto com uma presunção de racionalidade e de suficiência de informação sobre as circunstâncias que as cercam. (MACCORMICK, 2008, p. 182)

Há, nos votos da ADPF 153, uma composição entre vários tipos de argumentos - linguísticos, sistêmicos e teleológico-avaliativos -, que se articulam para fornecer uma resposta adequada à seguinte questão: se a anistia concedida pelo parágrafo $1^{\circ}$ do artigo $1^{\circ}$ da Lei n. $6.683 / 79$ poderia ou não ser estendida aos agentes públicos do Estado, que praticaram crimes comuns contra os opositores do regime. À exceção dos votos do Ministro Marco Aurélio e da Ministra Ellen Gracie, que suscitam dúvidas quanto à pertinência dos apoios e das garantias trazidas, pode-se dizer que, em geral, os votos da ADPF 153 são racionais - posto que se utilizam de argumentos jurídicos - e justificados.

Para que a síntese aqui desenvolvida seja o mais completa possível, é preciso organizar a investigação, de modo a tocar em três aspectos principais: primeiro, o da consistência; segundo, o da coerência; terceiro, o da universalizabilidade. Tais pontos referem-se tanto aos votos, individualmente, quanto à íntegra da decisão.

Sobre a consistência, esta pode ser definida como a mera ausência de contradição lógica. A decisão, como um todo, apresenta-se livre de contradições, sendo, portanto, uma decisão consistente. Mais especificamente sobre os votos, dois deles suscitam dúvidas quando comparados a tal critério de análise. $\mathrm{O}$ argumento central do voto do Ministro Marco Aurélio possui uma linha de desenvolvimento um pouco sinuosa, vez que 
aborda uma série de aspectos distintos, que não chegam a ser concluídos - ao menos não de maneira clara e evidente. Sendo assim, ousa-se dizer que o voto do Ministro Marco Aurélio não atente, plenamente, o requisito da consistência.

O voto da Ministra Ellen Gracie também gera algumas dúvidas a respeito de sua consistência. As imprecisões identificadas, contudo, restringem-se à pertinência da garantia e de seu respectivo apoio, apresentados para os argumentos. Desse modo, não é adequado qualificar tal voto como um voto que deixa de atender o requisito da consistência. É certo que surgem dúvidas a respeito da pertinência de algumas alegações, mas que não chegam a mitigar, de maneira significativa, tal aspecto do voto.

A coerência normativa, por sua vez, tem a ver com valores ${ }^{5}$, que são “[...] estados de coisas cuja busca é legítima, desejável, valiosa ou mesmo [...] obrigatória, na condição de propósitos, objetivos ou fins." (MACCORMICK, 2008, p. 251). A coerência normativa depende de que as normas "façam sentido", em virtude de serem racionalmente relacionadas, como um conjunto que está orientado para a realização de valores comuns.

Em resumo, a coerência de um conjunto de normas é função de sua justificabilidade sob princípios e valores de ordem superior, desde que os princípios e valores de ordem superior ou suprema pareçam aceitáveis, quando tomados em conjunto, no delineamento de uma forma de vida satisfatória. (MACCORMICK, 2008, p. 253)

Diante desse quadro, cabe a seguinte questão: como a coerência normativa se relaciona com o caso da ADPF 153? Ou melhor, em que medida a decisão proferida neste caso se concilia com os princípios e valores que conferem sentido ao conjunto de normas - leis e precedentes, no caso - de nosso ordenamento? Se as regras forem entendidas como determi-

5 MacCormick sugere que haveria uma sobreposição entre princípios e valores, na medida em que, para cada valor $\mathrm{V}$, haveria um princípio correspondente em que $\mathrm{V}$ poderia ser perseguido ou realizado. Assim, a observância a princípios se mostraria uma forma eficaz de realizar valores. Afirma: "Princípios jurídicos dizem respeito a valores operacionalizados localmente dentro de um sistema jurídico estatal ou de alguma ordem normativa análoga." (MACCORMICK, 2008, p. 251-252) 
nações ou concretizações dos princípios, soluções e decisões que surgem em um contexto tal devem atender ao requisito da coerência com o direito preexistente.

A questão da coerência deve, então, ser situada em dois momentos distintos: o da edição da Lei de Anistia, e o atual contexto, em que aquela Lei foi submetida à apreciação no Supremo Tribunal Federal. Sob o ângulo da formulação das leis, supõe-se que o Legislador exerce a atividade que lhe é incumbida segundo a intenção de legislar coerentemente. Assevera MacCormick (2008, p. 260):

Um legislador que respeita o Estado de Direito não pode escolher, arbitrariamente, exercer o poder legislativo sem considerar o modo pelo qual novas leis se sustentam dentro do sistema jurídico como um todo.

O autor coloca a questão em termos muito claros, ao afirmar que o Legislador deve executar sua tarefa coerentemente, sempre em respeito ao sistema jurídico como um todo. Neste caso específico, cabe dizer que, apesar de o contexto em que a Lei n. 6.683/79 ter sido um contexto autoritário, os legisladores não atuavam à margem de quaisquer pressupostos, muito pelo contrário. Havia não apenas uma história institucional, mas, principalmente, leis e precedentes que serviam de parâmetros à atividade legislativa. Ainda que o regime não fosse democrático, não se atuava em uma espécie de "vácuo institucional".

Assim, não se deve buscar uma intenção legislativa que sustente uma interpretação no sentido de estender a anistia aos agentes públicos do Estado, pois esta contraria os limites da coerência com o direito existente em um sistema jurídico. Ademais, conforme elucidado pelos Ministros Lewandowski e Ayres Britto, havia - e ainda há - normas que especificam as possibilidades normativas de conexão criminal, além de delitos que à época já estavam tipificados nos Códigos Penal e Militar, aos quais os atos praticados por agentes públicos poderiam se enquadrar.

$\mathrm{Na}$ atual conjuntura, revela-se ainda mais incoerente uma interpretação tal qual a que foi atribuída à ADPF 153. Não há como se esquivar - e isso não seria nem mesmo desejável - dos valores e princípios que 
estruturam e conferem sentido ao ordenamento jurídico brasileiro. À luz dos aspectos valorativos, essenciais em um Estado Democrático de Direito, tem-se que a decisão em questão foge de um parâmetro normativo de coerência, e chega a alcançar até mesmo os valores de segurança jurídica e certeza do direito. Segundo MacCormick (2008, p. 264):

A coerência pode ser vista como relevante para a justificação, pois] está em conformidade com uma certa concepção de racionalidade na vida prática, concepção que exige tanto universalidade, quanto o maior grau de generalidade possível nos princípios práticos. Há também razões (informação adequada a pessoas afetadas pelo Direito, relativa clareza no Direito e previsibilidade razoável a sua aplicação) para que o Direito deva se expressar por meio de regras relativamente detalhadas. [...] Dito de outro modo, as disposições detalhadas do sistema devem ser interpretadas como se estivessem servindo a um conjunto de valores mutuamente compatíveis. 'Coerência' pode, então, ser ao menos parcialmente satisfeita por um sistema que se refere racionalmente ao que os responsáveis por determinar seu conteúdo consideram como valores.

É de se mencionar que a coerência, como uma compatibilidade axiológica entre duas ou mais regras, todas justificáveis em vista de um princípio ou lugar comum, tem um caráter eminentemente dinâmico, e não estático. Isso significa que o ideal de coerência normativa é uma coerência através do sistema e ao longo do tempo, isto é, a cada momento, o sistema deve exibir coerência como um sistema momentâneo - embora sujeito a mudanças. É possível que, no que concerne à Lei de Anistia, o ideal da coerência foi sobrepujado também sob a ótica retrospectiva. Falhou-se ao editar uma norma que concedia anistia a agentes públicos que teriam praticado delitos comuns e, novamente, quando a mesma interpretação foi entendida válida.

A coerência figura, portanto, como uma característica ideal de um sistema jurídico. Embora esta não seja uma garantia suficiente de justiça, é uma razão justificadora que leva a um direito "preferível" - um sistema do direito coerente, evidentemente, é mais desejável que o incoerente. A coerência normativa, conectada a valores e princípios jurídicos, que ex- 
pressam uma forma de vida satisfatória, apresenta um desafio perpétuo e candente ao Estado de Direito. Afirma-se, por conseguinte, que a decisão apresentada pelo Supremo Tribunal Federal, de alguma maneira, falha com tal ideal de coerência, pelo fato de não se apresentar em consonância com a dimensão valorativa inafastável em um Estado Democrático de Direito.

Apontou-se que a falta de atendimento ao requisito da coerência poderia mitigar, até mesmo, o valor da segurança jurídica. Deve-se esclarecer que, no caso da ADPF 153, essa mesma ideia poderia ser utilizada em prol do contra-argumento. A alegação seria a seguinte: a mudança da interpretação de uma norma, que perdura por mais de três décadas, seria a real responsável por atingir a segurança jurídica. Acredita-se que este argumento não prospera, uma vez que não é possível utilizar um valor do próprio sistema jurídico para se contrapor, de algum modo, ao ideal mais profundo de coerência daquele - ao qual, inclusive, a justiça se conecta.

Retoma-se a distinção traçada anteriormente, a respeito dos argumentos sistêmicos e teleológico-avaliativos. A título de exemplo, é possível aproveitar o argumento trazido repetidamente à ADPF 153 que justifica a validade da Lei de Anistia a partir da intenção de "transição pacífica" do sistema ditatorial para o democrático. Ora, por óbvio, o ideal de coerência não se sobrepõe à intenção de um texto normativo, ou vice-versa. Há que se dizer, somente, que ambos os requisitos caminham lado-a-lado, isto é, a vontade normativa final de uma norma deve, obrigatoriamente, estar em consonância com o a coerência do sistema ao qual a norma pertence.

$\mathrm{O}$ ato de interpretação de uma norma em um sistema jurídico - um conjunto inter-relacionado de normas, que possuem uma base comum de validade formal - deve pressupor uma ideia de fonte normativa final. Daí que o argumento do instrumento de "superação" de um regime para outro da Lei n. 6.683/79 não poderia ser trazido para a justificação.

É preciso fazer algumas considerações sobre a universalizabilidade. Supõe-se que a interpretação conferida à Lei de Anistia (Lei n. 6.683/79), na ADPF 153, constitua uma decisão excepcionável (defeasible), em outras palavras, uma decisão que representa uma exceção em face dos demais casos similares. Sobre tal conceito, aduz MacCormick (2008, p. 311): 
O que é relevante sobre a defeasibility é que um arranjo construído com base em regras jurídicas, ou algum estado de coisas jurídico que emerge a partir de um conjunto de regras e eventos, pode ter uma aparência de validade e, no entanto, este arranjo ou 'fato institucional' pode ainda estar sujeito a algum tipo de intervenção que o invalide. Aquilo que inicialmente era reconhecida ou aparentemente válido, torna-se aberto à contestação e passível de perder sua validade, ou mesmo revelar-se como inválido desde sempre, apesar de todas as aparências. Em outras palavras, o arranjo [...] em questão é excepcionável (defeasible), e os eventos invalidantes provocam a exceção (defeasance).

Ainda que se arriscasse sustentar que a solução apresentada na ADPF 153 se trata de um caso excepcionável - uma exceção juridicamente justificada, em condições ordinariamente necessárias e presumivelmente suficientes -, haveria obstáculos para alcançar tal desígnio. O impasse da universalizabilidade não poderia, de maneira alguma, ser superado.

Colocando a questão em outros termos, ocorre que qualquer decisão judicial está sujeita ao requisito da universalizabilidade de suas razões, de seus argumentos. Por mais rara que seja a situação de que trata um caso concreto, a argumentação construída deve ser testável como uma decisão universal, que pode ter suas razões reproduzidas em qualquer outro caso análogo. Então, como seria possível enfrentar tal empecilho na ADPF 153? Acredita-se que não há uma saída plausível ou minimamente razoável para tal indagação.

É certo que uma decisão que se apresenta incoerente, em maior ou menor medida, com o Estado de Direito, não pode, nem deve, ser universalizada para qualquer outro caso similar. Assim, ao que nos parece, a decisão proferida na ADPF 153, nos moldes em que reinterpretou a Lei de Anistia (Lei n. 6.683/79), não poderia ser encarada como um "caso exceção", pela razão maior de não ter uma justificativa razoável ao ponto de poder ser estendida a outros casos, por contrariar a universalizabilidade. MacCormick (2008, p. 328) afirma: "Universais excepcionáveis são, contudo, ainda universais." 
No decorrer deste trabalho, procurou-se revisitar três aspectos essenciais de decisões judiciais, salientados por Neil MacCormick: os requisitos da consistência, da coerência, e da universalizabilidade. Quanto ao primeiro, não houve maiores problemas quanto à existência da consistência na maior parte dos votos da ADPF 153. Mediante a análise do segundo e do terceiro aspecto, constatou-se que a decisão proferida na ADPF 153 foi inadequada do ponto de vista da coerência e, por conseguinte, da impossibilidade de universalização. Conclui-se dizendo que, por mais que se possa dizer que a decisão da ADPF 153 foi racional e justificada, não se apresenta como a solução mais apropriada para o caso, por conta da incoerência dessa frente aos princípios e aos valores defendidos no Estado Democrático de Direito.

Em que pese a importância da análise realizada sob os pressupostos da teoria jurídica contemporânea, é forçoso reconhecer que, o tema que aqui se trata, tangencia aspectos mais amplos e complexos sobre anistia e justiça de transição. Acredita-se ser apropriado encerrar o trabalho fazendo menção à incoerência da decisão proferida na ADPF 153 com o contexto global da construção da justiça transicional. De acordo com Anthony Pereira,

Embora a América Latina ocupe a linha de frente dessa onda de justiça transicional, o Brasil manteve-se relativamente afastado dessa tendência geral. [...] o Brasil distingue-se pelo fato de seu governo ter se dedicado muito pouco para tratar da violência praticada pelo regime militar. Além de tentativas atrasadas e pouco divulgadas de investigar a morte e o desaparecimento de algumas das vítimas do regime militar e de indenizar as famílias, a atitude oficial do governo brasileiro com relação à justiça transicional foi, principalmente, de silêncio e amnésia. (PEREIRA, 2010, p. 25)

A Corte Interamericana de Direitos Humanos - CIDH reconheceu, no Caso Gomes Lund e Outros ("Guerrilha do Araguaia") VS. Brasil, que as disposições da Lei de Anistia que impedem a investigação e punição pelas graves violações de direitos humanos cometidas são incompatíveis com a Convenção Americana de Direitos Humanos, com o integral res- 
peito aos direitos humanos e, por isso, não deve seguir representando um obstáculo para a investigação e punição dos responsáveis.

Destarte, a decisão proferida pelos Ministros e Ministras do Supremo Tribunal Federal no caso da ADPF 153 se mostra incoerente tanto do ponto de vista do direito interno, quanto do direito internacional humanitário. Embora o caso já tenha sido julgado pelo STF, há a mencionada decisão da Corte Interamericana de Direitos Humanos, que reabre o cenário e projeta para o futuro novos desafios e soluções. A síntese proposta neste trabalho não se pretendeu superadora, mas provisória, até mesmo para que se permaneçam abertos e atentos às novas alternativas que surgem para dilema da justiça de transição no Brasil.

\section{Referências}

BRASIL. Supremo Tribunal Federal. Arguição de Descumprimento de Preceito Fundamental n. 153. Inteiro Teor do Acórdão. Relator: Ministro Eros Grau. Abril, 2010. Disponível em: $<$ http://redir.stf.jus.br/paginadorpub/paginador.jsp?docTP=AC\&docID=612960>. Acesso em: 3 ago. 2011 .

. Lei n. 6.683, de 28 de agosto de 1979. Disponível em: $<$ http:// www.planalto.gov.br/ccivil_03/leis/L6683.htm>. Acesso em: 3 ago. 2011. BRETON, Phillipe; GAUTHIER, Gilles. História das Teorias da Argumentação. Lisboa: Editorial Bizâncio, 2001.

CORTE Interamericana de Direitos Humanos. 2010. Sentença de 24 de novembro. Gomes Lund e Outros ("Guerrilha do Araguaia") v. Brasil. 2010.

MACCORMICK, Neil. Retórica e o Estado de Direito. Rio de Janeiro: Elsevier, 2008.

PEREIRA, Anthony. Ditadura e repressão: o autoritarismo e o Estado de Direito no Brasil, no Chile e na Argentina. São Paulo: Paz e Terra, 2010.

PERELMAN, Chaim; OLBRECHTS-TYTECA, Lucie. Tratado da Argumentação: a nova retórica. São Paulo: Martins Fontes, 1996.

TOULMIN, Stephen E. Os usos do argumento. São Paulo: Martins Fontes, 2006. 